\title{
Calcaneal Fractures: Controversy in Treatment
}

\author{
Claribel Plain Pazos ${ }^{1 *}$, Leonardo Dominguez Plain ${ }^{2}$, Sergio Morales Pineiro ${ }^{3}$, Carmen Rosa Carmona Penton ${ }^{1}$, \\ Anisbel Perez de Alejo Plain ${ }^{4}$, Juan Carlos Cedre Gonzalez ${ }^{5}$ and Daily Calero Ruiz ${ }^{6}$ \\ ${ }^{1}$ Specialist of I and II Degree in Comprehensive General Medicine, Assistant Professor, Faculty of Medical Sciences of Sagua la Grande, Cuba \\ ${ }^{2} 3^{\text {rd }}$ year Orthopedic Resident, Provincial General University Hospital “Mártires del 9 de Abril”, Cuba \\ ${ }^{3}$ Specialist of I and II Degree in Orthopedic, Assistant Professor, Provincial General University Hospital "Mártires del 9 de Abril", Sagua la Grande, Cuba \\ ${ }_{4}^{4} 3^{\text {rd }}$ Year Student of Medicine, Faculty of Medical Sciences of Sagua la Grande, Cuba \\ ${ }^{5}$ Specialist of I Degree in Orthopedic, Assistant Professor, Provincial General University Hospital "Martires del 9 de Abril", Sagua la Grande, Cuba
}

${ }^{6}$ Degree in Nursing, Instructor teacher, Provincial General University Hospital “Martires del 9 de Abril”, Sagua la Grande, Cuba

Submission: February 16, 2021; Published: March 26, 2021

*Corresponding author: Claribel Plain Pazos, Specialist of I and II Degree in Comprehensive General Medicine, Faculty of Medical Sciences of Sagua la Grande, Cuba

\section{Opinion}

Calcaneal fractures are the most common of the tarsal bones. It is common for them to occur after traffic accidents or due to rainfall in the work environment, [1,2] mainly in young people [2], and they are considered severe injuries that generate a high degree of disability [1,2]. They account for approximately $60 \%$ of fractures affecting the tarsus and $1.2 \%$ of all fractures $[2,3]$. In $70 \%$ of cases there is joint involvement [1], around $75 \%$ are intra-articular, compromising the subtalar joint [3], and even in the $26 \%$ of the subjects can find other associated lesions [1].

Intra-articular calcaneal fractures are characterized by the existing controversy regarding their treatment, since for the same fracture we can find very different solutions and opinions $[4,5]$, although the literature agrees that the available evidence is insufficient to affirm that surgical treatment is superior to conservative [2]. Currently the treatment of choice is open reduction and internal fixation (ORIF) [2,5]. However, minimally invasive techniques, through the sinus tarsi approach (AST), have become in recent years an increasingly popular option among foot and ankle surgeons $[2,4]$.

A widely used classification for its prognostic value in the treatment of intra-articular calcaneal fractures is the Sanders classification, which is based on coronal CT assessment of the posterior subtalar facet, according to the number of fragments of this facet displaced more than two millimeters [6,7]. Although its high intra- and inter-observer variability has been criticized, it is still the reference classification. In addition, its value in predicting subtalar arthrodesis has been demonstrated (there is 5.5 times more probability of ending in subtalar arthrodesis in a Sanders IV than a Sanders II). Differentiates four main types: $[8,9]$

i. Type I: without displacement or displaced $<2 \mathrm{~mm}$, subsidiary of orthopedic treatment.

ii. Type II: in two fragments or split fractures (subdivided into $\mathrm{A}, \mathrm{B}$ and $\mathrm{C}$, depending on the fracture that sits laterally, centrally medially in the thalamus). Greater severity, the lesser is the anteromedial fragment.

iii. Type III: in three fragments or split depression (subdivided into III $\mathrm{AB}, \mathrm{AC}$ and $\mathrm{BC}$ ).

iv. Type IV: in four fragments or comminuted fractures.

The objectives in the treatment of intra-articular calcaneal fractures are to correct the height, width and length of the heel, $[2,5]$ to reconstruct the depression of the posterior subtalar joint, to release the submaleolar impingement and the compression on the peroneal tendons produced by the fragment of the lateral wall, as well as correcting the varus or valgus deformity [5]. Open surgical treatment is associated with a high rate of complications (20$30 \%)$, such as wound dehiscence (10\%), deep infection (5-22\%) and even amputation (2-2.5\%), lengthening the convalescence and darkening the prognosis. To avoid postoperative morbidity associated with open surgical treatment, multiple authors have sought alternatives through percutaneous techniques and limited approaches to reduce the risk of soft tissue damage [5]. Among 
the factors to consider for the surgical approach is the fracture pattern, which, framing itself in the Sanders classification, is proposed: [7]

a. Sanders's type I, closed treatment.

b. Sanders's type II and III, open reduction.

c. Sander's type IV, closed reduction and in hands experienced primary arthrodesis.

The approach through minimal incisions to resolve a calcaneal fracture requires knowledge of the anatomy of the calcaneus, as well as anatomical landmarks and measures to avoid complications with internal fixation [4]. It is the most experienced specialists who must undertake this treatment. In several studies carried out it has been possible to verify that the Sanders classification is an important prognostic factor of calcaneal fractures, together with the injury mechanism and the age of the patients $[2,4,5]$. It depends largely on these three factors future evolution of the patient. Given the severity and complexity of this type of injury, associated with the rate of surgical complications and physical sequelae that they entail, calcaneal fractures continue to be a real challenge for the orthopedic surgeon [2]. Without a doubt, in the event of a calcaneal fracture, a good assessment of the case as a whole and a correct selection of the treatment technique to be used is a guarantee for the prognosis to be expected. The goal is not only to treat the fracture, but to ensure that the patient has the best possible future quality of life. The training and skill of the surgeon is a decisive factor in the quality of the results.

\section{References}

1. Lobo Escolar L, Arias Baile A, Berlanga De-Mingo D, M E Gaviria-Parada, A Dalmau-Coll (2017) Factores relacionados con las complicaciones del tratamiento quirúrgico de las fracturas de calcáneo. Rev Pie Tobillo 31(2): 115-123.
2. Diranzo García J, Bertó Martí X, Castillo Ruiperez L, Estrems Díaz V, Hernández Ferrando L, et al. (2019) Tratamiento de las fracturas intraarticulares de calcáneo mediante placa de reconstrucción. Resultados y complicaciones de 86 fracturas. Rev Esp Cir Ortop Traumatol 62(4): 267-273.

3. Moreno López J, Moreno Palacios JA, García Delgado I, Epalza DíazGuardamino E, Ruiz Sanz M, et al. (2019) Fractura por avulsión de tipo II de la tuberosidad posterior del calcáneo (en pico de pato). Serie de casos. Rev Colomb Ortop Traumatol 32(3): 197-201.

4. Slullitel G, Calvi J, Calvo A, Seletti M, Lopez V, et al. (2016) Análisis imagenologico del calcaneo aplicada a la fijacion interna de fracturas a traves del abordaje del seno del tarso. Acta OrtopMex 30(4): 181-184.

5. Gonzalez Garcia D, Blazquez Martin T, San Miguel Campos M, Iglesias Duran E (2016) Tratamiento percutaneo con balon de cifoplastia de las fracturas intraarticulares de calcáneo:resultados. Rev Pie Tobillo 30(2): 87-93.

6. Sanders R, Fortin P, Di Pasquale T, Walling A (1993) Operative treatment in 120 displaced intraarticular calcaneal fractures. Results using a prognostic computed tomography scan classification. Clin Orthop Relat Res 290: 87-95.

7. Morales Santos G, Uriarte Pacheco FV, Sánchez Ventura ML (2004) Fracturas de calcáneo. Rev Hosp Jua Mex 71(4): 167-176.

8. Herrera Pérez M, Gutiérrez Morales MJ, Valderrabano V, Wiewiorski M, Pais Brito JL (2019) Fracturas de calcáneo: controversias y consensos. Rev Pie Tobillo 30(1): 1-12.

9. Sanders R (2019) Intra-articular fractures of the calcaneus: Present state of the art. J Orthop Trauma 6: 252-265.

\section{Your next submission with Juniper Publishers will reach you the below assets}

- Quality Editorial service

- Swift Peer Review

- Reprints availability

- E-prints Service

- Manuscript Podcast for convenient understanding

- Global attainment for your research

- Manuscript accessibility in different formats ( Pdf, E-pub, Full Text, Audio)

- Unceasing customer service

Track the below URL for one-step submission https://juniperpublishers.com/online-submission.php 